IZA DP No. 10015

The Intimate Link between Income Levels and Life Expectancy: Global Evidence from 213 Years

Michael Jetter

Sabine Laudage

David Stadelmann

June 2016 


\title{
The Intimate Link between Income Levels and Life Expectancy: Global Evidence from 213 Years
}

\author{
Michael Jetter \\ University of Western Australia \\ and IZA \\ Sabine Laudage \\ University of Bayreuth \\ David Stadelmann \\ University of Bayreuth
}

\author{
Discussion Paper No. 10015 \\ June 2016
}

IZA

P.O. Box 7240

53072 Bonn

Germany

Phone: +49-228-3894-0

Fax: +49-228-3894-180

E-mail: iza@iza.org

\begin{abstract}
Any opinions expressed here are those of the author(s) and not those of IZA. Research published in this series may include views on policy, but the institute itself takes no institutional policy positions. The IZA research network is committed to the IZA Guiding Principles of Research Integrity.

The Institute for the Study of Labor (IZA) in Bonn is a local and virtual international research center and a place of communication between science, politics and business. IZA is an independent nonprofit organization supported by Deutsche Post Foundation. The center is associated with the University of Bonn and offers a stimulating research environment through its international network, workshops and conferences, data service, project support, research visits and doctoral program. IZA engages in (i) original and internationally competitive research in all fields of labor economics, (ii) development of policy concepts, and (iii) dissemination of research results and concepts to the interested public.
\end{abstract}

IZA Discussion Papers often represent preliminary work and are circulated to encourage discussion. Citation of such a paper should account for its provisional character. A revised version may be available directly from the author. 


\section{ABSTRACT}

\section{The Intimate Link between Income Levels and Life Expectancy: Global Evidence from 213 Years}

Contrary to previous findings, we find a systematic and economically sizeable relationship between income levels and life expectancy in a panel dataset of 197 countries over 213 years. By itself, GDP/capita explains more than 64 percent of the variation in life expectancy. The Preston curve prevails, even when accounting for country- and time-fixed effects, country-specific time trends, and alternative control variables. Quantile regressions and instrumental variable estimations suggest this link to be persistent across different levels of life expectancy and unaffected by reverse causality. If policymakers want to prolong people's lives, economic growth appears to be the predominant medicine.

JEL Classification: I15, I31, J11, H51

Keywords: historical panel data, income levels, life expectancy, quantile regression analysis

Corresponding author:

Michael Jetter

Business School

University of Western Australia

35 Stirling Highway

Crawley, WA 6009

Australia

E-mail: mjetter7@gmail.com 


\section{Introduction}

In a seminal work, Samuel Preston (1975) outlined the non-linear relationship between a country's income levels and the expected lifespan of its citizens. Labeled the "Preston curve," the hypothesis states that poor countries enjoy a substantial increase in life expectancy when they grow, whereas this effect diminishes, yet remains positive, for richer countries. Recently, however, Preston (2007) himself has questioned this relationship, arguing that GDP per capita may at times explain no more than 16 percent of the variation in life expectancy. Similarly, Spence and Lewis (2009) argue the Preston curve "may not hold within countries over time," lamenting the unavailability of long-run data to test the Preston curve (see also Leon, 2007, and Mackenbach, 2007).

This paper provides a systematic long-term study of the relationship between income levels and life expectancy, using data for 197 countries and 213 years. Our first result produces considerable evidence for a powerful income-life expectancy link. By itself, GDP per capita (linear, squared, and cubic) is able to explain over 64 percent of the variation in life expectancy for our full sample of 4,325 country-decade observations. ${ }^{1}$ This constitutes four times the explanatory power suggested by Preston (2007).

Second, a major advantage of using repeated country-level data comes from the opportunity to control for any country- and time-specific heterogeneity via fixed effects. Naturally, countries differ vastly in terms of history, culture, institutional roots, as well as geography. Many of these factors could independently be associated with life expectancy. However, the predictive power of income levels remains strong (both in terms of statistical significance and magnitude) after controlling for country- and time-fixed effects, country-specific time trends, population size, conflicts, health care spending, the occurrence of Malaria, and political institutions. Causality appears to be running from income

\footnotetext{
${ }^{1}$ Even between 1930 and 1970, where previous papers have claimed that the explanatory power of income has weakened, the corresponding $\mathrm{R}^{2}$ never drops below 47 percent.
} 
to life expectancy (employing instrumental variables) and the relationship does not vary at different stages of life expectancy (using quantile regressions).

Finally, our results allow for a quantitative interpretation of the derived relationship. In our most complete estimation, income levels remain a strong positive predictor of life expectancy until approximately US $\$ 15,478$ (corresponding to about 95 percent of observations in our sample), after which the relationship flattens out. Indeed, our findings

lend support to the traditional intuition of the Preston curve, as poor countries experience larger jumps in life expectancy when their economy grows. Furthermore, the effect remains robust and remarkably stable in terms of magnitude throughout all time periods.

From a policy perspective, our findings suggest that large parts of the relative ill health in poor countries is a result of their being poor. The predominant medicine for longer lives seems to be raising the level of income per capita to that of rich countries. International health interventions and innovation may contribute to raising life expectancy, but existing and fundamental differences in life expectancy between countries are mostly due to differences in income. Thus, higher incomes buy a longer life.

We proceed with a discussion of the related literature in Section 2. The data and the empirical strategy are presented in Section 3, whereas Section 4 provides the main results, along with several robustness checks and extensions. Section 5 offers concluding remarks and policy implications.

\section{Literature and Background}

Large gains in life expectancy have been a global phenomenon over the course of the 20th century. In our sample of 197 countries, the average life expectancy more than doubled 
from the year 1900 to 2000 from 33.42 years to 68.18 years. ${ }^{2}$ Nevertheless, citizens in poor countries continue to live shorter lifes than those of rich countries. In general, little doubt remains that raising incomes can help to improve the level of health and extend life expectancy. However, the dominant drivers of life expectancy are hotly debated and opinions diverge (see Strauss and Thomas, 1998, Acemoglu et al., 2001, McArthur and Sachs, 2001, Acemoglu and Johnson, 2007, and Weil, 2007, among others).

In a seminal paper, Preston (1975) declares innovations in modern medicine as the driving forces in explaining large upward shifts in life expectancy, arguing that income only exerts an indirect effect via the consumption of health items. To underpin his thesis, Preston (1975) conducts a cross-country analysis of national income per capita and mortality rates for the 1900s, 1930s, and 1960s. The respective samples include ten, 38, and 57 countries. ${ }^{3}$ Plotting both variables for the available countries and time periods in one diagram, he draws the so-called "Preston curve" through the corresponding data points which provide a clear relationship between the two variables with an upward shift for each of the observed time periods.

Since then, the Preston curve has been investigated extensively (see Cutler et al., 2006, Bloom and Canning, 2007, Leon, 2007, Wilkinson, 2007, Mackenbach and Looman, 2013, and Edwards, 2016). Empirical results have been mixed and a common critique of the Preston curve relates to the idea that other, exogenous factors are driving developments in life expectancy, such as the introduction of new vaccines, medical treatments, or post-war campaigns.

Revisiting the topic, Preston (2007, p.486) himself argues that "[f]actors exogenous

\footnotetext{
${ }^{2}$ Oeppen et al. (2002) suggest there is no reason to believe humanity will stop pushing the boundaries of life expectancy and Soares (2007) discusses the development of life expectancy in poorer nations in the 20th century.

${ }^{3}$ Data used for life expectancy and income per capita are mainly taken from the UN Demographic Yearbook in 1967 (for updated data, see http://unstats.un.org/unsd/demographic/products/dyb/ dyb2.htm) and the UN Statistical Yearbook.
} 
to a country's current level of income probably account for $75-90 \%$ of the growth in life expectancy for the world as a whole between the 1930s and the 1960s." Similarly, Dalgaard and Strulik (2014) estimate the Preston curve for the year 2000 and only find a modest direct effect of income on longevity, but a much larger indirect impact via health care efficiency (see also Evans et al., 2001, and Joumard et al., 2010). Thus, income levels may only play a minor role. In turn, Pritchett and Summers (1996) argue that GDP per capita carries a large and causal impact on life expectancy. ${ }^{4}$ In a cross-country analysis of five-year intervals from 1960 to 1990, they find changes in income to be responsible for approximately 40 percent of the observed improvements in life expectancy. The causal direction is underpinned by an instrumental variable regression structure, using the terms of trade as instruments, among other variables.

How can we reconcile these findings and how important are income levels in extending the average life span? Our study accounts for endogeneity via the inclusion of countryand time-fixed effects, country-specific time trends, and variables capturing alternative explanations in civil conflict, health care expenditure, the prevalence of malaria, and political institutions. In particular, controlling for two-way fixed effects allows us to isolate the income-life expectancy relationship from country- and time-specific heterogeneity. ${ }^{5}$ For example, colonial history and institutional roots (e.g., see Acemoglu et al., 2005, and the literature cited therein), as well as geographical aspects, such as climate zones, disease prevalence, and distance to the coast, have been suggested as drivers of development levels (e.g., see Sachs, 2003). Similarly, cultural particularities are likely associated with income levels (see Tabellini, 2010) and such characteristics may plausibly exert independent effects

\footnotetext{
${ }^{4}$ Lindahl (2005) provides micro evidence from analyzing lottery prize winners and finds a robust and sizeable effect of income on life expectancy and Angel (2016) reports negative effects of low income and over-indebtedness on health for 25 European countries.

${ }^{5}$ The introduction of country- and time-fixed effects has affected a number of standard results in the literature. Examples can be found for economic growth (Islam, 1995), democracy (Acemoglu et al., 2008), and government size (Ram, 2009).
} 
on life expectancy, e.g., through the degree of risk aversion in living one's life. All such time-invariant country-specific characteristics will be absorbed by country-fixed effects.

Related to time-fixed effects, we can think of specific global developments that may influence life expectancy and income levels simultaneously, such as major wars or technological advancements. For example, if the invention of new vaccines (see Preston, 2007) or the post-war period in the middle of the 20th century were largely responsible for global upward shifts in life expectancy, then time-fixed effects would soak up that variation and income levels should lose their explanatory power in terms of statistical relevance and magnitude. ${ }^{6}$ Finally, incorporating country-specific time trends acknowledges the idea that each society has emerged in its own unique way and we wish to ensure that the income-life expectancy link is not driven by such heterogeneity. ${ }^{7}$ Note that previous studies did not have rich panel data at their disposal to account for unobservable heterogeneity along the country and time dimension (Pritchett and Summers, 1996, is a notable exception).

In fact, data availability has long been a major concern in the associated literature and studies using repeated country-level observations have struggled to find evidence for the role of GDP per capita. For instance, Mackenbach (2007) highlights that increasing interdependencies between countries make the usage of cross-sectional data less reliable. Spence and Lewis $(2009$, p.9) argue that "[a]lthough the Preston curve shows a close relationship between income and health in the cross-sectional data, longitudinal data will suggest that this relationship may not hold within individual countries over time." Our results show the opposite, employing panel data for 197 countries and 213 years. Even in the contested time period between 1930 and 1970, income levels alone are able to explain

\footnotetext{
${ }^{6}$ Contrary to Preston, 2007, we can also think of a hypothesis under which medical innovations strengthen the relationship between income and life expectancy; new treatments usually become available worldwide, but are only used in countries where people have sufficient means to pay for them.

${ }^{7}$ For example, Leon (2007) argues that in some African countries life expectancy declines due to HIV/AIDS and in post-Soviet countries institutions prohibit life expectancy from rising. Similarly, sharp increases in life expectancy occurred in different eras for the developed and less developed countries (see Preston, 2007).
} 
47 to 66 percent of the cross-country variation in life expectancy.

\section{$3 \quad$ Data and Empirical Strategy}

\subsection{Data}

Our panel data set includes 197 countries for the years 1800 to 2012. The data set is almost completely balanced, as only one country is missing information for five decades (Morocco) and four countries are missing information for one decade (French Guiana, Guadeloupe, Martinique, and Reunion). To alleviate concerns about measurement errors, we follow the associated literature (e.g. Pritchett and Summers, 1996) in averaging all annual variables over a decade. Nevertheless, all derived results are consistent when employing five- or 20-year averages (corresponding results can be found in Table A3). The first decade ranges from 1800 until 1809, whereas the second decade spans the years 1810 to 1819 , and so on. In the final period, we average annual values from 2010 until 2012.

For the two main variables of interest, life expectancy and GDP per capita, we access data provided by the Gapminder Foundation (Rosling, 2009). Data on life expectancy is compiled and standardized from several official international statistics, historical sources, and estimates made by the Gapminder statisticians. Among the main sources are the $\mathrm{Hu}-$ man Mortality Database (Wilmoth et al., 2014), the World Population Prospects (United Nations, 2013), and the Human Lifetable Database (Max Planck Institute for Demographic Research, 2016). ${ }^{8}$ Data on income per capita is compiled in a similar way. ${ }^{9}$

\footnotetext{
${ }^{8}$ Initial data sources can be accessed via www.mortality.org, http://esa.un.org/unpd/wpp/, and www.lifetable.de. Gapminder data is available under http://www.gapminder.org/data/. Gapminder provides a complete documentation how the data is compiled and standardized on its website.

${ }^{9}$ Gapminder states that "[c]ross-country data for 2005 by the International Comparison Program forms the main source of the reference year. Real income per capita growth rates were linked to the 2005 levels." Several sources are employed, among others the data of Angus Maddison, available under The
} 
Importantly, country-fixed effects in our analysis account for the notion that measurement in some countries can be more problematic than in others. Time-fixed effects are intended to control for the idea that data quality may have improved over time. Finally, our analysis also controls for country-specific time trends, accounting for specific national developments over time.

Following the previous literature, we also control for independent effects of population size, conflict prevalence, health care expenditure, the incidence of malaria, and the degree of democracy (see Pritchett and Summers, 1996, Acemoglu et al., 2005, Plümper and Neumayer, 2006, or Acemoglu et al., 2008). ${ }^{10}$ These estimations are intended to evaluate whether any changes in life expectancy associated with income levels could be driven by an omitted variable beyond our fixed-effects framework. All variables come from standard sources of country-level data and summary statistics are referred to Table A1. Finally, Table A2 provides a list of all sample countries with their average life expectancy and income levels.

\subsection{Main Empirical Strategy}

Our main empirical strategy employs a multiple regression approach, where we regress life expectancy in years on a linear, a quadratic, and a cubic term of GDP per capita, acknowledging the original concept of the Preston curve (Preston, 1975).

Our first goal is to estimate how much of the variation in life expectancy can be explained by income levels alone. Following previous studies, we then subsequently incorporate country-fixed effects (represented by $\delta_{i}$ in the following), measures for population size and conflict incidence (included in $\boldsymbol{X}_{i t}$ ), time-fixed effects $\left(\vartheta_{t}\right)$, and country-specific

Maddison-Project (2013).

${ }^{10}$ Note that earlier data for population size has been interpolated linearly, in order to preserve sample size. Nevertheless, our results show that population size does not play a relevant role in affecting the income-life expectancy link. 
time trends $\left(\omega_{i t}\right) \cdot{ }^{11}$ In extensions, we also include health care spending, a measure for malaria prevalence, and the degree of democracy which are excluded from the main analysis because of limited data availability. In particular, we estimate

$$
L E_{i t}=\beta_{0}+\beta_{1}\left(\frac{G D P}{c a p}\right)_{i t}+\beta_{2}\left(\frac{G D P}{c a p}\right)_{i t}^{2}+\beta_{3}\left(\frac{G D P}{c a p}\right)_{i t}^{3}+\delta_{i}+\boldsymbol{X}_{i t} \beta_{4}+\vartheta_{t}+\omega_{i t}+\epsilon_{i t}
$$

Finally, $\epsilon_{i t}$ constitutes the conventional error term. Note that standard errors are clustered on the country-level throughout all estimations.

\subsection{Quantile Analysis}

Our final check for the income-life expectancy link considers specific ranges of life expectancy. In econometric terms, an OLS analysis produces coefficients at the mean of the distribution, allowing for a general conclusion. However, it is possible that income levels have raised the average lifespan more so when lives were generally shorter in the early time period of our sample. Advances may have been simpler when life expectancy was still relatively low, whereas substantial jumps may be more difficult if a country already exhibits an average life expectancy of, say, 60 years.

To test for such heterogeneity, we employ a quantile regression approach for panel data, as introduced by Harding and Lamarche (2009) and Canay (2011). In particular, this technique allows us to account for unobserved heterogeneity and heterogeneous effects of the covariates. Further, we follow Canay (2011) in applying the deviation of the countryspecific mean in life expectancy, thereby acknowledging country-specific particularities. The resulting two-stage estimator remains consistent and asymptotically normal, with

\footnotetext{
${ }^{11}$ Population size and life expectancy are considered to have a recursive relation where one can reinforce or hamper the other (Acemoglu and Johnson, 2007). Plümper and Neumayer (2006) argue that inner-or inter-state (armed) conflicts have direct negative effects on people's life expectancy (victims of military operations), but also indirect restrictive effects through limited agricultural production, insufficient public health care provision and social disorder.
} 
standard errors computed using a bootstrap methodology. These estimations allow us to consider the income-life expectancy nexus from another angle, testing whether the main results hold up for different ranges of life expectancy.

\section{Empirical Findings}

\subsection{Main Results}

To get an idea of the global situation on our key variables, Figure 1 visualizes life expectancy and income levels in the first decade of the 21st century. Just from comparing both maps, we can already tell that the two variables are intimately related, at least in recent years.

Table 1 turns to our regression results from estimating equation 1. Column (1) displays results from a univariate regression and income indeed offers itself as a strong predictor of life expectancy. Over 39 percent of the variation in life expectancy can be explained by a linear term of GDP per capita alone. Column (2) introduces the familiar shape of the original Preston curve, taking into account a squared and a cubic term of income levels. Indeed, we find evidence for nonlinearity and saturation appears to set in at approximately US\$26,246 (which would affect less than 2.5 percent of our sample observations). After this value, the income-life expectancy relationship is suggested to flatten out.

Note that the model's fit is improved substantially in column (2) and we are now able to explain over 64 percent of the variation in life expectancy across countries over time which is a high explanatory power when analyzing social phenomena with a single variable. These basic regressions suggest a much more intimate relationship between a country's wealth and the duration of the average life than previously suggested. In particular, Preston (2007, p.487) states that only 16 percent of the increase in life expectancy between 

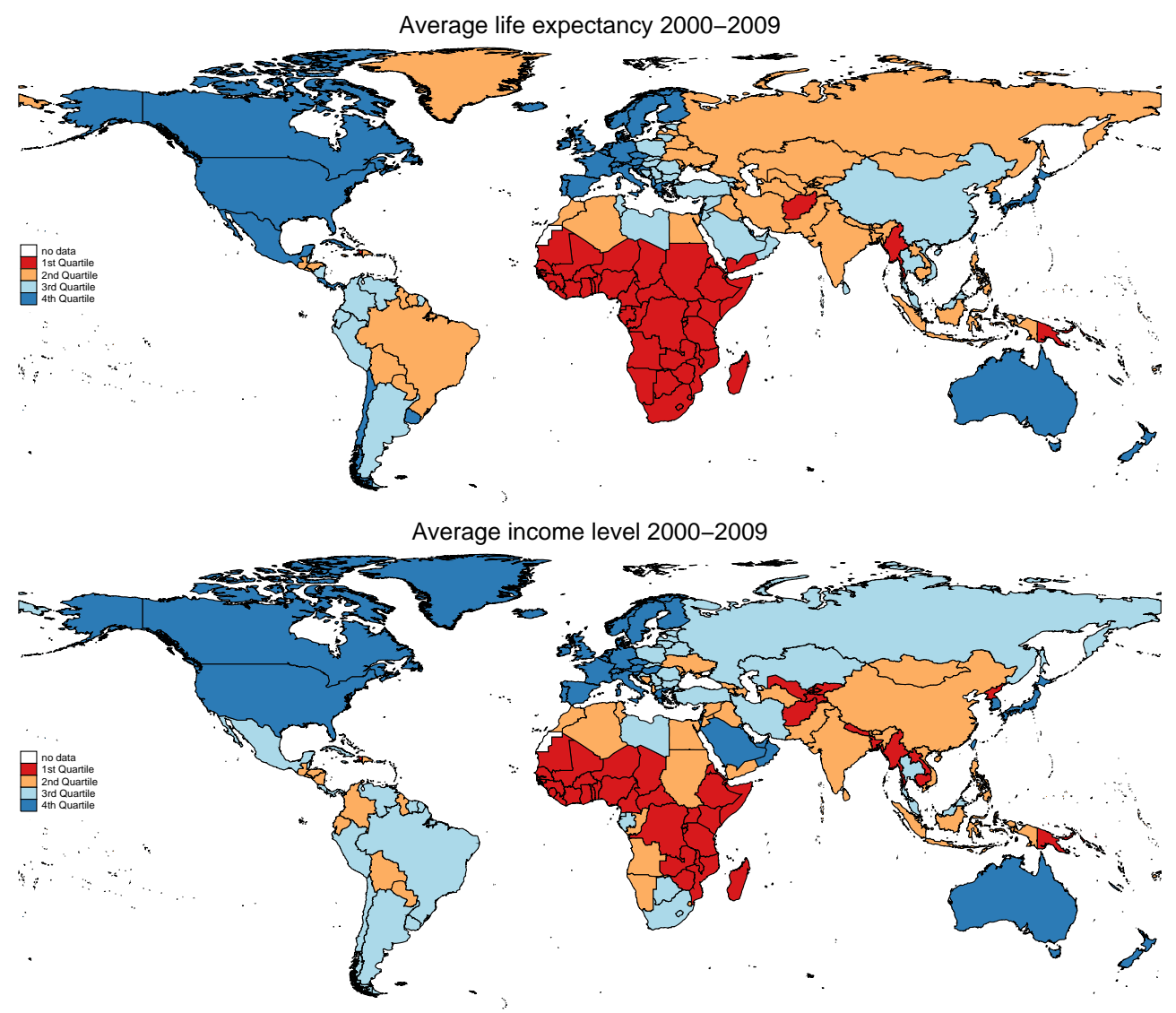

Notes: Life expectancy is categorized into quartiles: $\mathrm{LE}<62.65,62.65<\mathrm{LE}<71.52,71.52<\mathrm{LE}<75.45$, and LE $>75.45$. Similarly, income levels are categorized into quartiles: GDP/cap $<2,102,2,102<$ GDP $/$ cap $<6,435$, $6,435<\mathrm{GDP} /$ cap $<15,677$, and GDP $/$ cap $>15,677$.

Figure 1: Map of average life expectancy and income levels from $2000-2009$. 
Table 1: Results from OLS regressions, estimating life expectancy in years. All variables are taken as 10-year averages and the overall sample timeframe includes the years $1800-2012$.

\begin{tabular}{|c|c|c|c|c|c|c|}
\hline & $(1)$ & $(2)$ & $(3)$ & $(4)$ & $(5)$ & $(6)$ \\
\hline \multicolumn{7}{|c|}{ Dependent variable: Life expectancy in years } \\
\hline GDP/cap in US\$10,000 & $\begin{array}{c}13.958^{* * *} \\
(1.850)\end{array}$ & $\begin{array}{c}46.594^{* * *} \\
(2.742)\end{array}$ & $\begin{array}{c}50.954^{* * *} \\
(3.556)\end{array}$ & $\begin{array}{c}36.065^{* * *} \\
(3.532)\end{array}$ & $\begin{array}{c}14.331^{* * *} \\
(1.785)\end{array}$ & $\begin{array}{c}4.100^{* * *} \\
(1.442)\end{array}$ \\
\hline$\left(\mathrm{GDP} /\right.$ cap in US\$10,000) ${ }^{2}$ & & $\begin{array}{c}-11.900^{* * *} \\
(1.369)\end{array}$ & $\begin{array}{c}-13.013^{* * *} \\
(1.713)\end{array}$ & $\begin{array}{c}-9.210^{* * *} \\
(1.280)\end{array}$ & $\begin{array}{c}-3.723^{* * *} \\
(0.708)\end{array}$ & $\begin{array}{c}-1.617^{\text {*** }} \\
(0.545)\end{array}$ \\
\hline$\left(\mathrm{GDP} / \mathrm{cap}\right.$ in US\$10,000) ${ }^{3}$ & & $\begin{array}{c}0.768^{* * *} \\
(0.133)\end{array}$ & $\begin{array}{c}0.845^{* * *} \\
(0.160)\end{array}$ & $\begin{array}{c}0.594^{* * *} \\
(0.108)\end{array}$ & $\begin{array}{c}0.247^{* * *} \\
(0.061)\end{array}$ & $\begin{array}{c}0.126^{* * *} \\
(0.045)\end{array}$ \\
\hline Population size & & & & $\begin{array}{c}6.612^{* * *} \\
(1.058)\end{array}$ & $\begin{array}{c}1.357^{* * *} \\
(0.416)\end{array}$ & $\begin{array}{l}1.684^{* *} \\
(0.734)\end{array}$ \\
\hline Conflict & & & & $\begin{array}{c}0.522^{* * *} \\
(0.190)\end{array}$ & $\begin{array}{l}-0.144 \\
(0.097)\end{array}$ & $\begin{array}{l}-0.116 \\
(0.071)\end{array}$ \\
\hline Country fixed effects & & & yes & yes & yes & yes \\
\hline Time fixed effects & & & & & yes & yes \\
\hline Country-specific time trends & & & & & & yes \\
\hline Threshold value GDP/cap ${ }^{a}$ & & 26,246 & 26,332 & 26,241 & 25,946 & 15,478 \\
\hline \# of countries & 197 & 197 & 197 & 197 & 197 & 197 \\
\hline \# of decades & 21 & 21 & 21 & 21 & 21 & 21 \\
\hline$N$ & 4,325 & 4,325 & 4,325 & 4,325 & 4,312 & 4,312 \\
\hline Adjusted $R^{2}$ & 0.391 & 0.644 & 0.693 & 0.806 & 0.925 & 0.956 \\
\hline
\end{tabular}

Notes: Standard errors clustered on the country level are displayed in parentheses. ${ }^{*} p<0.10,{ }^{* *} p<0.05,{ }^{* * *} p<0.01$. ${ }^{a} \mathrm{GDP} /$ cap value above which the income-life expectancy link flattens out. 
1938 and 1963 for the world as a whole would be attributable to increases in average income per se. Our results, using global data for 213 years, provide a much stronger conclusion in favor of the income-life expectancy link.

The statistically significant linear, quadratic and cubic terms imply an S-shaped relationship between income and life expectancy. This S-shape is suggestive for the causal link going from income to life expectancy. Suppose causality ran instead from life expectancy to income, then income would have to rise independently for low and high levels of life expectancy to satisfy the S-shape in the GDP per capital-life expectancy plain. While possible, this does not seem probable to us. On the other hand, it is intuitively conceivable that additional income at initially low and high levels of economic development has only modest effects on life expectancy: For low levels for GDP per capita, additional income is first spend on current consumption with little impact on life expectancy and for high levels of GDP per capita, additional income only buys relatively little health as higher life expectancy comes at ever higher marginal costs. ${ }^{12}$ We further explore the causal relationship between income and life expectancy in the next section.

To further investigate Preston's specific claim related to the middle of the 20th century, Figure 2 visualizes the respective $\mathrm{R}^{2}$ values when estimating a pure cross-sectional regression for each decade. Regressions only incorporate GDP per capita (linear, squared, and cubic) to predict life expectancy. Ever since the early 20th century income levels alone explain between 45 and 66 percent of the cross-country variation in life expectancy. ${ }^{13}$ Only before 1880 do we observe $\mathrm{R}^{2}$ values under 0.42 , but even then the suggested contribution of 16 percent is comfortably surpassed, as the minimum $\mathrm{R}^{2}$ we derive reaches a value of 0.25 (years $1800-1809$ ). Note that it is possible that early values suffer from

\footnotetext{
${ }^{12}$ Note that we do not suggest that there are no potential effects of life expectancy on income. Rather, the main driver of life expectancy seems to be income which buys health.

${ }^{13}$ In alternative estimations, we also employed the natural logarithm to income levels. The corresponding regressions produce even higher $\mathrm{R}^{2}$ values throughout over entire sample and the respective graph is referred to Figure 3.
} 
measurement error, which may explain less statistical precision, compared to data from the 20 th and 21st century.

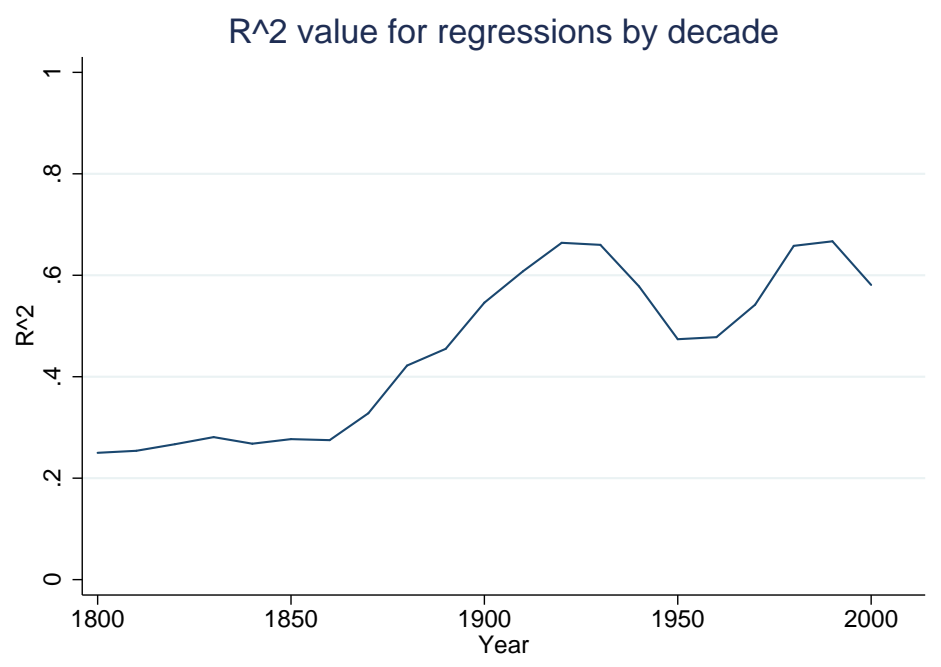

Figure 2: $\mathrm{R}^{2}$ values for cross-sectional regressions by decade.

Returning to Table 1, column (3) includes country-fixed effects, yet the relevance of income levels remains virtually unchanged. Note that we estimate an almost identical threshold level after which the suggested relationship flattens out with US\$26,332. Thus, it is unlikely that unobservable heterogeneity on the country level is driving the importance of income levels. In fact, running a regression where we only use country-fixed effects to predict life expectancy (absent income levels) produces an $\mathrm{R}^{2}$ value of only 0.154 - not even one quarter of the 64.4 percent explained by income levels alone in column (2). Thus, income levels are much stronger in predicting longer lives than any country-specific characteristics, such as cultural particularities or historical aspects.

Columns (4) to (6) add further control variables to improve the model's precision and to check whether the power of income levels can be explained by other factors. Specifically, we include population size, conflict status, time-fixed effects, and country-specific time trends. However, all three income variables retain their explanatory power and remain 
statistically significant on the one percent level. Note that the inclusion of time-fixed effects implicitly controls for the alternative explanation of global health care developments (e.g., vaccines and treatments). Finally, once country-specific time trends are accounted for, the threshold level after which the income-life expectancy link flattens out diminishes to US\$15,478. Although this value appears much less than in the previous regressions, it would only affect approximately five percent of the entire sample observations.

\subsection{Alternative Explanations}

With these benchmark results in mind, Table 2 turns to several alternative explanations for the strong link between GDP per capita and life expectancy. In particular, we check for the roles of health care expenditure per capita, the prevalence of malaria, the level of democracy, and potentially underlying endogeneity. In columns (1) through (6), we first replicate our baseline regression using only those observations for which each respective control variable is available. Then, we include the additional control variable to observe potential changes in our results. Note that we exclude country-fixed effects and countryspecific time trends, given the limited number of observations of only two or three decades, respectively.

First, we further evaluate the role of medical developments by including health expenditure per capita. Several papers (e.g., Preston, 1975, and Dalgaard and Strulik, 2014) have argued that substantial advances in health care, specifically vaccines and medical breakthroughs between 1940 and 1959, are responsible for systematic changes in life expectancy. Indeed, we find that higher spending on health care is associated with longer lives. In quantitative terms, an increase of US $\$ 1,000$ per capita is associated with living for 1.4 additional years, on average. Nevertheless, the role of income levels remains virtu-

ally unchanged, as the respective coefficients remain significant on the one percent level 
and the corresponding threshold level after which the income-life expectancy link flattens out changes only marginally.

Columns (3) and (4) conduct the same exercise for the prevalence of malaria. As expected, life expectancy increases if malaria is largely absent. Yet, here again, the importance of income levels prevails and malaria prevalence is not able to explain the importance of GDP per capita. Moving to a measure for formal institutions, columns (5) and (6) consider the level of democracy, applying the Polity IV indicator (variable polity 2 , ranging from -10 , total autocracy, to +10 , total democracy). The results indicate that people in more democratic nations enjoy longer lives, but these findings are not able to account for the importance of income levels.

Finally, columns (7) through (10) address potential endogeneity concerns related to reverse causality. Intuitively, longer lives may in turn affect GDP per capita, a possibility that has received attention in the associated literature via several channels (e.g., see Acemoglu and Johnson, 2007, and Oster et al., 2013). In general, it is well known that endogeneity concerns in macroeconomic variables are difficult to disentangle. Ideally, a researcher requires an instrumental variable that is completely unrelated to the outcome variable, but strongly correlated with the potentially endogenous regressor. We offer four instrumental variable (IV) strategies as a remedy.

Our first solution focuses on using lagged values of the potentially endogenous regressor as instruments - a popular solution in the literature. ${ }^{14}$ In our context, values of life expectancy in a decade are unlikely to affect income levels today. Our second solution follows Easterly et al. (1993) and Pritchett and Summers (1996) by subsequently employing trade (measured in percent of GDP) and the investment-to-GDP ratio as instruments.

\footnotetext{
${ }^{14}$ See Temple (1999), Schularick and Steger (2010), and Mirestean and Tsangarides (2016) for using lagged values of endogenous variables to estimate economic growth. Bhattacharyya and Hodler (2010) instrument democracy with its lagged value and Arezki and Brückner (2011) employ lagged corruption values as an instrument for corruption today.
} 


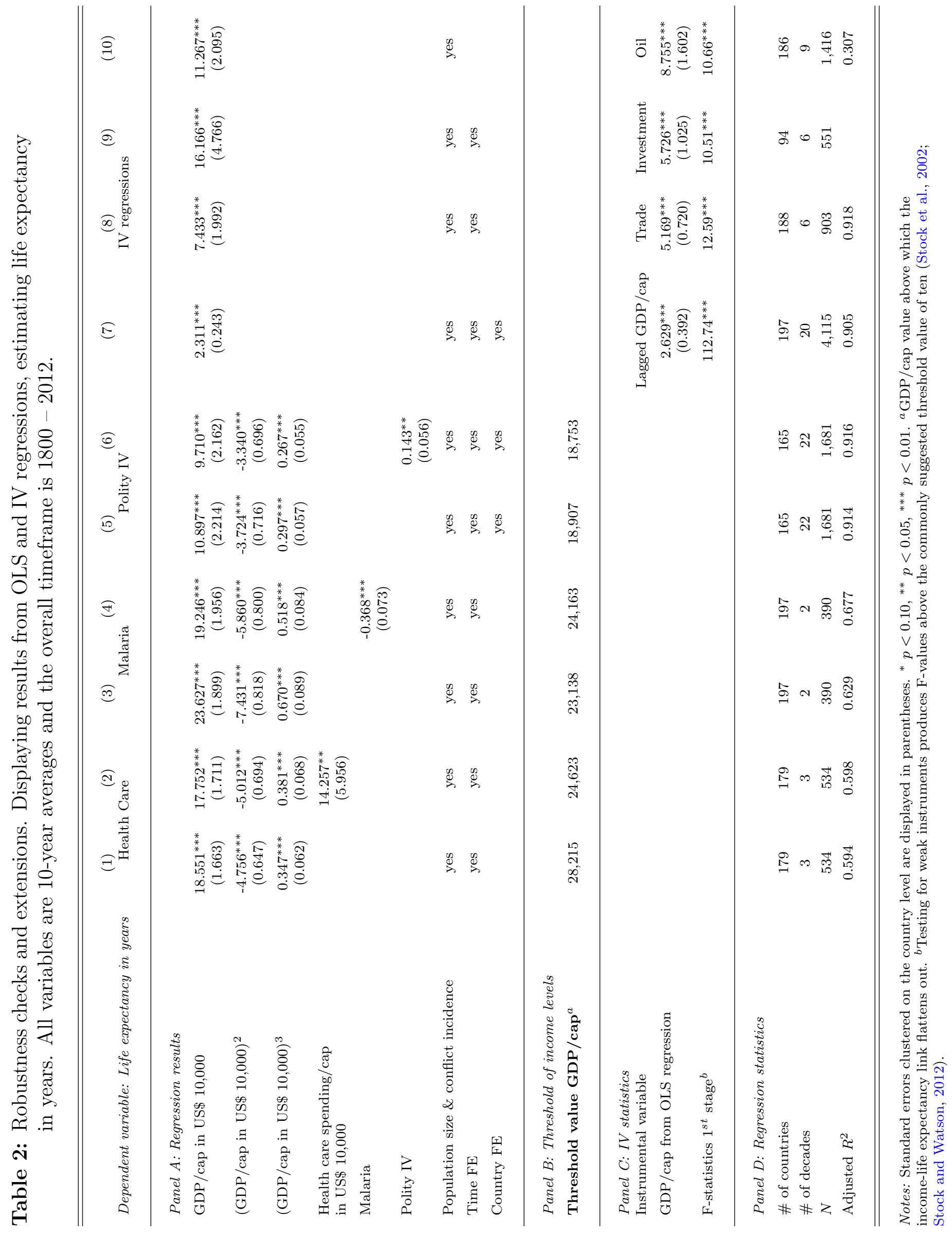


In particular, a country's extent of international trade is likely related to income levels, but meaningful independent channels to life expectancy are difficult to imagine. ${ }^{15}$ Levine and Renelt (1992) show that the ratio of investment is robustly related to growth (also see detailed explanation in Pritchett and Summers, 1996). In our final attempt at circumventing reverse causality concerns, we employ oil reserves as an instrumental variable. Such natural phenomena are directly linked to income levels (e.g., Brückner et al., 2012), yet are unlikely to be related to life expectancy through other meaningful channels. ${ }^{16}$ Note that we exclude country-fixed effects from the final three regressions, as the statistical variation from the respective instruments is not sufficient to produce meaningful IV estimates. We also intended to instrument for squared and cubic values of income levels, but the corresponding higher order values of the respective instruments do not provide sufficient statistical variation, rendering them unsuitable.

To conveniently assess whether the corresponding IV results are in line with results from analogous OLS regressions, Panel $\mathrm{C}$ of Table 2 displays the respective coefficient on the linear term of GDP per capita. For example, in column (7), when employing lagged values of GDP per capita, the coefficient from the IV regression reaches a value of 2.3, whereas the corresponding coefficient from an OLS regression (using the same sample) returns a value of 2.6. Thus, we observe little difference in the quantitative relationship between income levels and life expectancy in the IV framework. In terms of statistical relevance, the derived coefficient remains statistically significant on the one percent level. Similarly, the respective coefficients in columns (8) through (10) confirm the importance of income levels. In these estimations, the coefficient from employing the respective IV structure even surpasses the OLS estimate. Thus, overall, Table 2 produces little evidence for the claim that reverse causality may drive the role of income levels in explaining life

\footnotetext{
${ }^{15}$ For the trade-income link, we refer to classical trade models, such as Heckscher-Ohlin, or recent empirical contributions, e.g., from Irwin and Terviö (2002).

${ }^{16}$ We access data provided by Cotet and Tsui (2013) for oil reserves per capita.
} 
expectancy.

\subsection{Quantile Regression Results}

Finally, we move to results from quantile regressions, evaluating whether the role of income levels persists across the entire spectrum of life expectancy. Table 3 displays the corresponding results, where we resort to the baseline regression format of employing linear, squared, and cubic values of GDP per capita to estimate life expectancy. We also include our main control variables with population size and conflict incidence.

Table 3: Quantile regression results, estimating life expectancy in years. All variables are 10-year averages and the overall timeframe is $1800-2012$.

\begin{tabular}{|c|c|c|c|c|c|c|}
\hline & $(1)$ & $(2)$ & $(3)$ & $(4)$ & $(5)$ & (6) \\
\hline & OLS & Q 0.1 & Q 0.25 & Q 0.5 & Q 0.75 & Q 0.9 \\
\hline \multicolumn{7}{|c|}{ Dependent variable: Life expectancy in years } \\
\hline GDP/cap in US\$10,000 & $\begin{array}{c}14.331^{* * *} \\
(1.785)\end{array}$ & $\begin{array}{c}15.141^{* * *} \\
(0.951)\end{array}$ & $\begin{array}{c}15.800^{* * *} \\
(1.107)\end{array}$ & $\begin{array}{c}14.653^{* * *} \\
(1.164)\end{array}$ & $\begin{array}{l}12.951^{* * *} \\
(1.480)\end{array}$ & $\begin{array}{c}14.420^{* * *} \\
(1.420)\end{array}$ \\
\hline$(\mathrm{GDP} / \text { cap in US } \$ 10,000)^{2}$ & $\begin{array}{c}-3.723^{* * *} \\
(0.708)\end{array}$ & $\begin{array}{c}-3.714^{* * *} \\
(0.502)\end{array}$ & $\begin{array}{c}-4.280^{* * *} \\
(0.573)\end{array}$ & $\begin{array}{c}-4.472^{* * *} \\
(0.598)\end{array}$ & $\begin{array}{c}-3.971^{* * *} \\
(0.757)\end{array}$ & $\begin{array}{c}-4.459^{* * *} \\
(0.867)\end{array}$ \\
\hline$(\mathrm{GDP} / \text { cap in US } \$ 10,000)^{3}$ & $\begin{array}{c}0.247^{* * *} \\
(0.061)\end{array}$ & $\begin{array}{c}0.228^{* * *} \\
(0.059)\end{array}$ & $\begin{array}{c}0.278^{* * *} \\
(0.075)\end{array}$ & $\begin{array}{c}0.360^{* * *} \\
(0.076)\end{array}$ & $\begin{array}{c}0.326^{* * *} \\
(0.096)\end{array}$ & $\begin{array}{c}0.372^{* * *} \\
(0.124)\end{array}$ \\
\hline Population size \& conflict incidence & yes & yes & yes & yes & yes & yes \\
\hline Time fixed effects & yes & yes & yes & yes & yes & yes \\
\hline Threshold value GDP/cap ${ }^{a}$ & 25,946 & 27,193 & 24,132 & 22,491 & 22,592 & 22,511 \\
\hline \# of countries & 197 & 197 & 197 & 197 & 197 & 197 \\
\hline $\begin{array}{l}N \\
\text { Adjusted } R^{2}\end{array}$ & $\begin{array}{l}4,312 \\
0.915\end{array}$ & 4,312 & 4,312 & 4,312 & 4,312 & 4,312 \\
\hline
\end{tabular}

Notes: Standard errors clustered on the country level are displayed in parentheses. ${ }^{*} p<0.10,{ }^{* *} p<0.05,{ }^{* * *} p<0.01$. ${ }^{a} \mathrm{GDP} /$ cap value above which the income-life expectancy link flattens out.

Column (1) replicates the OLS result to provide a benchmark of comparing the qualitative and quantitative effect of income on life expectancy. The remaining regressions 
display results for the 10 th and 25 th percentile, the median, the 75 th percentile, and the 90th percentile of the distribution. The corresponding coefficients remain remarkably consistent throughout these estimations. In addition, the associated threshold level after which the link flattens out remains stable and never falls below US $\$ 22,000$. These findings suggest that the income-life expectancy link prevails across all observed spans of life expectancy.

\section{Conclusions}

This paper revisits the relationship between income levels and life expectancy, analyzing data for 197 countries over 213 years (1800 to 2012). We investigate two central research questions. Firstly, how strong is GDP per capita in predicting life expectancy? And secondly, does the income-life expectancy link hold up once country- and time-specific heterogeneity is accounted for, as well as country-specific time trends and variables measuring alternative explanations, such as population size, conflicts, health expenditure, malaria prevalence, and political institutions?

The answer to the first question strongly confirms the initial hypothesis of the Preston curve, i.e., there exists a systematic non-linear relationship between income levels and the average lifespan within a country. All our estimations produce firm evidence of a consistently positive relationship until a value of approximately US\$15,478 (using international price levels in 2005), corresponding to approximately 95 percent of the 4,325 sample observations. GDP per capita alone is able to explain over 64 percent of the variation in life expectancy across countries and years.

The second question challenges previous studies that suggest the Preston curve only holds in cross-sectional studies, but disappears once exogenous country- and time-specific characteristics were considered. Our findings do not confirm this hypothesis. In fact, all 
three terms of income levels (linear, quadratic, and cubic) remain statistically significant on the one percent level in all our estimations and meaningful in terms of magnitude. Considering potential other drivers of life expectancy does not change our conclusion. Further, this result is unlikely to be driven by reverse causality concerns. Finally, we conduct quantile regressions and verify that the effect of income prevails throughout different stages of life expectancy.

Overall, analyzing virtually the entire world population since 1800 suggests that income levels are by far the strongest factor in raising life expectancy across the globe. Of course, medical innovations increase longevity, but richer countries are more likely to use these innovations and perform treatments because they can pay for them. Higher incomes permit countries to buy longevity and wealthier indeed means healthier. The ill health and short lifespans of the poor tend to be a result of their being poor and promoting economic growth is most likely one of the most powerful tools to guarantee healthy and long lives (also see Deaton, 2003). 


\section{References}

Acemoglu, D. and Johnson, S. (2007). Disease and development: The effect of life expectancy on economic growth. Journal of Political Economy, 115(6):925-985.

Acemoglu, D., Johnson, S., and Robinson, J. A. (2001). The colonial origins of comparative development: An empirical investigation. American Economic Review, 91(5):13691401.

Acemoglu, D., Johnson, S., and Robinson, J. A. (2005). Institutions as a fundamental cause of long-run growth. Handbook of Economic Growth, 1:385-472.

Acemoglu, D., Johnson, S., Robinson, J. A., and Yared, P. (2008). Income and democracy. American Economic Review, 98(3):808-842.

Angel, S. (2016). The effect of over-indebtedness on health: Comparative analyses for Europe. Kyklos, 69(2):208-227.

Arezki, R. and Brückner, M. (2011). Oil rents, corruption, and state stability: Evidence from panel data regressions. European Economic Review, 55(7):955-963.

Aten, B., Heston, A., and Summers, R. (2009). Penn World Table version 7.1. Center for International Comparisons of Production, Income, and Prices at the University of Pennsylvania.

Bhattacharyya, S. and Hodler, R. (2010). Natural resources, democracy and corruption. European Economic Review, 54(4):608-621.

Bloom, D. E. and Canning, D. (2007). Commentary: The Preston curve 30 years on: Still sparking fires. International Journal of Epidemiology, 36(3):498-499.

Brückner, M., Ciccone, A., and Tesei, A. (2012). Oil price shocks, income, and democracy. Review of Economics and Statistics, 94(2):389-399.

Canay, I. A. (2011). A simple approach to quantile regression for panel data. The Econometrics Journal, 14(3):368-386.

Cotet, A. M. and Tsui, K. K. (2013). Oil and conflict: What does the cross country evidence really show? American Economic Journal: Macroeconomics, 5(1):49-80.

Cutler, D., Deaton, A., and Lleras-Muney, A. (2006). The determinants of mortality. Journal of Economic Perspectives, 20(3):97-120.

Dalgaard, C.-J. and Strulik, H. (2014). Optimal aging and death: Understanding the Preston curve. Journal of the European Economic Association, 12(3):672-701. 
Deaton, A. (2003). Health, inequality, and economic development. Journal of Economic Literature, 41(1):113-158.

Easterly, W., Kremer, M., Pritchett, L., and Summers, L. H. (1993). Good policy or good luck? Journal of Monetary Economics, 32(3):459-483.

Edwards, R. B. (2016). Mining away the Preston curve. World Development, 78:22-36.

Evans, D. B., Tandon, A., Murray, C. J. L., and Lauer, J. A. (2001). Comparative efficiency of national health systems: Cross national econometric analysis. British Medical Journal, 323(7308):307-310.

Group, W. B. (2012). World Development Indicators 2012. World Bank Publications.

Harding, M. and Lamarche, C. (2009). A quantile regression approach for estimating panel data models using instrumental variables. Economics Letters, 104(3):133-135.

Irwin, D. A. and Terviö, M. (2002). Does trade raise income?: Evidence from the twentieth century. Journal of International Economics, 58(1):1-18.

Islam, N. (1995). Growth empirics: A panel data approach. The Quarterly Journal of Economics, 110(4):1127-1170.

Joumard, I., Andre, C., Nicq, C., and Chatal, O. (2010). Health status determinants: Lifestyle, environment, health care resources and efficiency. Environment, Health Care Resources and Efficiency, OECD Economics Department Working Paper, (627).

Leon, D. A. (2007). Commentary: Preston and mortality trends since the mid-1970s. International Journal of Epidemiology, 36(3):500-501.

Levine, R. and Renelt, D. (1992). A sensitivity analysis of cross-country growth regressions. American Economic Review, 82(4):942-963.

Lindahl, M. (2005). Estimating the effect of income on health and mortality using lottery prizes as an exogenous source of variation in income. Journal of Human resources, 40(1):144-168.

Mackenbach, J. P. (2007). Commentary: Did Preston underestimate the effect of economic development on mortality? International Journal of Epidemiology, 36(3):496-497.

Mackenbach, J. P. and Looman, C. W. (2013). Life expectancy and national income in Europe, 1900-2008: An update of Preston's analysis. International Journal of Epidemiology, 42(4):1100-1110.

Max Planck Institute for Demographic Research (2016). The human life-table database. Accessible via http: // www. lifetable. de. 
McArthur, J. W. and Sachs, J. D. (2001). Institutions and geography: Comment onAcemoglu, Johnson and Robinson. Technical report, National Bureau of Economic Research Working Paper \# 8114.

Mirestean, A. and Tsangarides, C. G. (2016). Growth determinants revisited using Limited-Information Bayesian Model Averaging. Journal of Applied Econometrics, 31(1):106-132.

Oeppen, J., Vaupel, J. W., et al. (2002). Broken limits to life expectancy. Science, 296(5570):1029-1031.

Oster, E., Shoulson, I., and Dorsey, E. (2013). Limited life expectancy, human capital and health investments. The American Economic Review, 103(5):1977-2002.

Plümper, T. and Neumayer, E. (2006). The unequal burden of war: The effect of armed conflict on the gender gap in life expectancy. International Organization, 60:723-754.

Preston, S. H. (1975). The changing relation between mortality and level of economic development. Population studies, 29(2):231-248.

Preston, S. H. (2007). The changing relation between mortality and level of economic development. International Journal of Epidemiology, 36(3):484-490.

Pritchett, L. and Summers, L. H. (1996). Wealthier is healthier. Journal of Human Resources, 31(4):841-868.

Ram, R. (2009). Openness, country size, and government size: Additional evidence from a large cross-country panel. Journal of Public Economics, 93(1):213-218.

Rosling, H. (2009). Gapminder. GapMinder Foundation, accessible via http: // www. gapminder. org, page 91.

Sachs, J. D. (2003). Institutions don't rule: Direct effects of geography on per capita income. Technical report, National Bureau of Economic Research.

Sarkees, M. R. and Wayman, F. (2010). Resort to war: 1816 - 2007. Correlates of War, Washington DC: CQ Press.

Schularick, M. and Steger, T. M. (2010). Financial integration, investment, and economic growth: Evidence from two eras of financial globalization. The Review of Economics and Statistics, 92(4):756-768.

Soares, R. R. (2007). On the determinants of mortality reductions in the developing world. Population and Development Review, 33(2):247-287.

Spence, M. and Lewis, M. A. (2009). Health and growth. World Bank Publications. 
Stock, J. H. and Watson, M. W. (2012). Introduction to Econometrics: Global Edition. Pearson Education.

Stock, J. H., Wright, J. H., and Yogo, M. (2002). A survey of weak instruments and weak identification in generalized method of moments. Journal of Business 8 Economic Statistics, 20(4):518-29.

Strauss, J. and Thomas, D. (1998). Health, nutrition, and economic development. Journal of Economic Literature, 36(2):766-817.

Summers, R. and Heston, A. (1991). The Penn World Table (mark 5): An expanded set of international comparisons, 1950-1988. The Quarterly Journal of Economics, $106(2): 327-68$.

Tabellini, G. (2010). Culture and institutions: Economic development in the regions of Europe. Journal of the European Economic Association, 8(4):677-716.

Temple, J. (1999). The new growth evidence. Journal of Economic Literature, 37(1):112156.

The Maddison-Project (2013). The maddison-project database, available under http: //www.ggdc.net/maddison/maddison-project/home.htm.

United Nations (2013). World population prospects: The 2012 revision. Population Division of the Department of Economic and Social Affairs of the United Nations Secretariat, New York.

Weil, D. N. (2007). Accounting for the effect of health on economic growth. The Quarterly Journal of Economics, 122(3):1265-1306.

Wilkinson, R. G. (2007). Commentary: The changing relation between mortality and income. International Journal of Epidemiology, 36(3):492-494.

Wilmoth, J., Andreev, K., Jdanov, D., Glei, D., Boe, C., Bubenheim, M., Philipov, D., Shkolnikov, V., and Vachon, P. (2014). Methods protocol for the Human Mortality Database.

World Health Organization (2015). Global health observatory data: Malaria; retrieved in 2015. 


\section{Appendix}

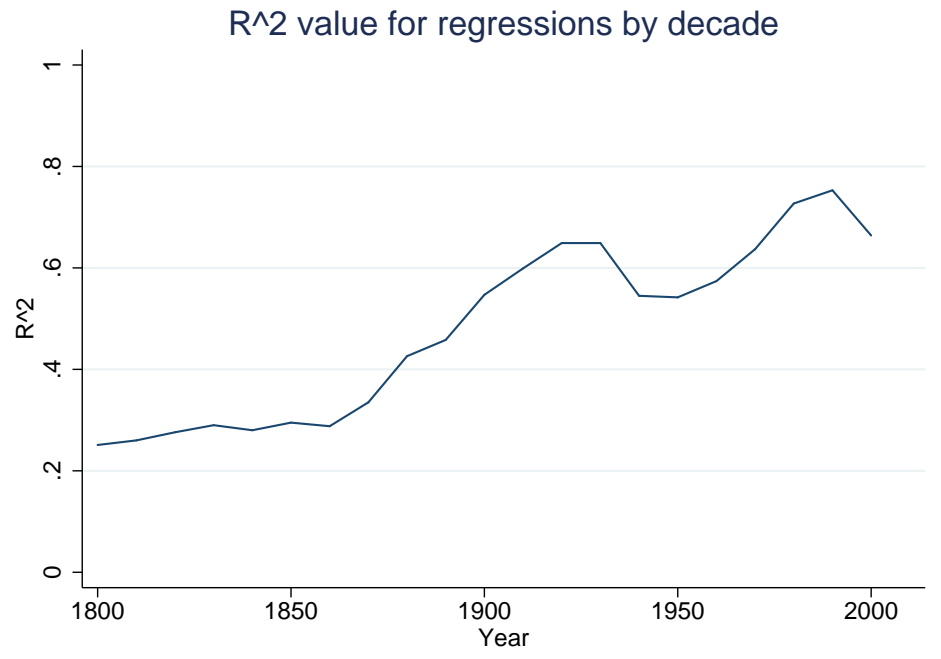

Figure 3: $\mathrm{R}^{2}$ values for cross-sectional regressions by decade, using the natural logarithm of GDP (linear, squared, and cubic). 
Table A1: Summary statistics.

\begin{tabular}{|c|c|c|c|c|c|c|}
\hline \multicolumn{2}{|l|}{ Variable } & \multirow{2}{*}{$\begin{array}{c}\text { Mean } \\
\text { (Std. Dev.) } \\
\\
\\
42.51 \\
(16.13)\end{array}$} & \multirow{2}{*}{$\begin{array}{c}\text { Min. } \\
\text { Max. } \\
\\
20.45 \\
(83.25)\end{array}$} & \multirow{2}{*}{$\begin{array}{c}\mathbf{N} \\
4,325\end{array}$} & \multirow{2}{*}{$\begin{array}{c}\text { Source }^{a} \\
\text { Gapminder }\end{array}$} & \multirow{2}{*}{$\begin{array}{l}\text { Description } \\
\text { The average number of years a newborn child } \\
\text { would live if current mortality patterns were } \\
\text { to stay the same }\end{array}$} \\
\hline Life expectancy & & & & & & \\
\hline GDP/cap in & US\$ & 0.36 & 0.03 & 4,325 & Gapminder & Gross Domestic Product per capita by \\
\hline & & $(0.72)$ & $(11.17)$ & & & $\begin{array}{l}\text { Purchasing Power Parities (in international } \\
\text { dollars, fixed } 2005 \text { prices) }\end{array}$ \\
\hline $\begin{array}{l}\text { Population size } \\
\text { (in millions) }\end{array}$ & & $\begin{array}{c}288 \\
(6,451)\end{array}$ & $\begin{array}{c}0.002 \\
(196,667)\end{array}$ & 4,325 & Gapminder & $\begin{array}{l}\text { Total Population, linearly interpolated for } \\
\text { earlier decades }\end{array}$ \\
\hline Conflict incidence & & $\begin{array}{c}0.37 \\
(1.36)\end{array}$ & $\begin{array}{c}0 \\
(10)\end{array}$ & 4,312 & Correlates of War & Number of intra-state and inter-state wars \\
\hline $\begin{array}{l}\text { Health care } \\
\text { expenditure }\end{array}$ & & $\begin{array}{c}0.09 \\
(0.12)\end{array}$ & $\begin{array}{c}0 \\
(0.86)\end{array}$ & 534 & World Bank & $\begin{array}{l}\text { Health expenditure per capita, PPP } \\
\text { (constant } 2011 \text { international } \$ \text { ) }\end{array}$ \\
\hline Malaria & & $\begin{array}{c}2.80 \\
(6.78)\end{array}$ & $\begin{array}{c}0 \\
(42.34)\end{array}$ & 392 & WHO & $\begin{array}{l}\text { Number of reported malaria cases in every } \\
100,000 \text { residents during the given year }\end{array}$ \\
\hline Polity IV & & $\begin{array}{l}-0.08 \\
(0.99)\end{array}$ & $\begin{array}{l}-10 \\
(1.96)\end{array}$ & 1,692 & World Bank & $\begin{array}{l}\text { Degree of democracy, ranging from }-10 \\
\text { (total autocracy) to }+10 \text { (total democracy), } \\
\text { variable polity } 2\end{array}$ \\
\hline Trade ( $\%$ of GDP) & & $\begin{array}{c}79.93 \\
(50.24)\end{array}$ & $\begin{array}{c}0 \\
(443.33)\end{array}$ & 906 & World Bank & Exports plus imports divided by GDP \\
\hline $\begin{array}{l}\text { Investment } \\
(\% \text { of GDP) }\end{array}$ & & $\begin{array}{l}22.09 \\
(9.08)\end{array}$ & $\begin{array}{c}1.82 \\
(76.51)\end{array}$ & 551 & PWT & $\begin{array}{l}\text { Investment share of PPP converted } \\
\text { GDP/capita at } 2005 \text { constant prices }\end{array}$ \\
\hline Oil in thousands & & $\begin{array}{c}258 \\
(3,003)\end{array}$ & $\begin{array}{c}0 \\
(73,314)\end{array}$ & 1,416 & Cotet \& Tsui & Oil reserves per capita from all sources \\
\hline
\end{tabular}

Notes: All variables are averaged per decade. ${ }^{a}$ Sources: Gapminder initially is introduced by Rosling (2009) and can now be found under http://www.gapminder.org/data/; World Bank: Group (2012); Correlates of War: Sarkees and Wayman (2010); WHO: World Health Organization (World Health Organization, 2015); PWT: Penn World Tables 7.1 (Aten et al., 2009, initially from Summers and Heston, 1991); Cotet \& Tsui: Cotet and Tsui (2013). ${ }^{b}$ To obtain continuous data for population size, we linearly interpolate yearly values from the years 1800-1950, where values for the years 1800 (available for 197 countries), 1820, 1870, and 1900 (available for most countries) are compiled from Gapminder. 


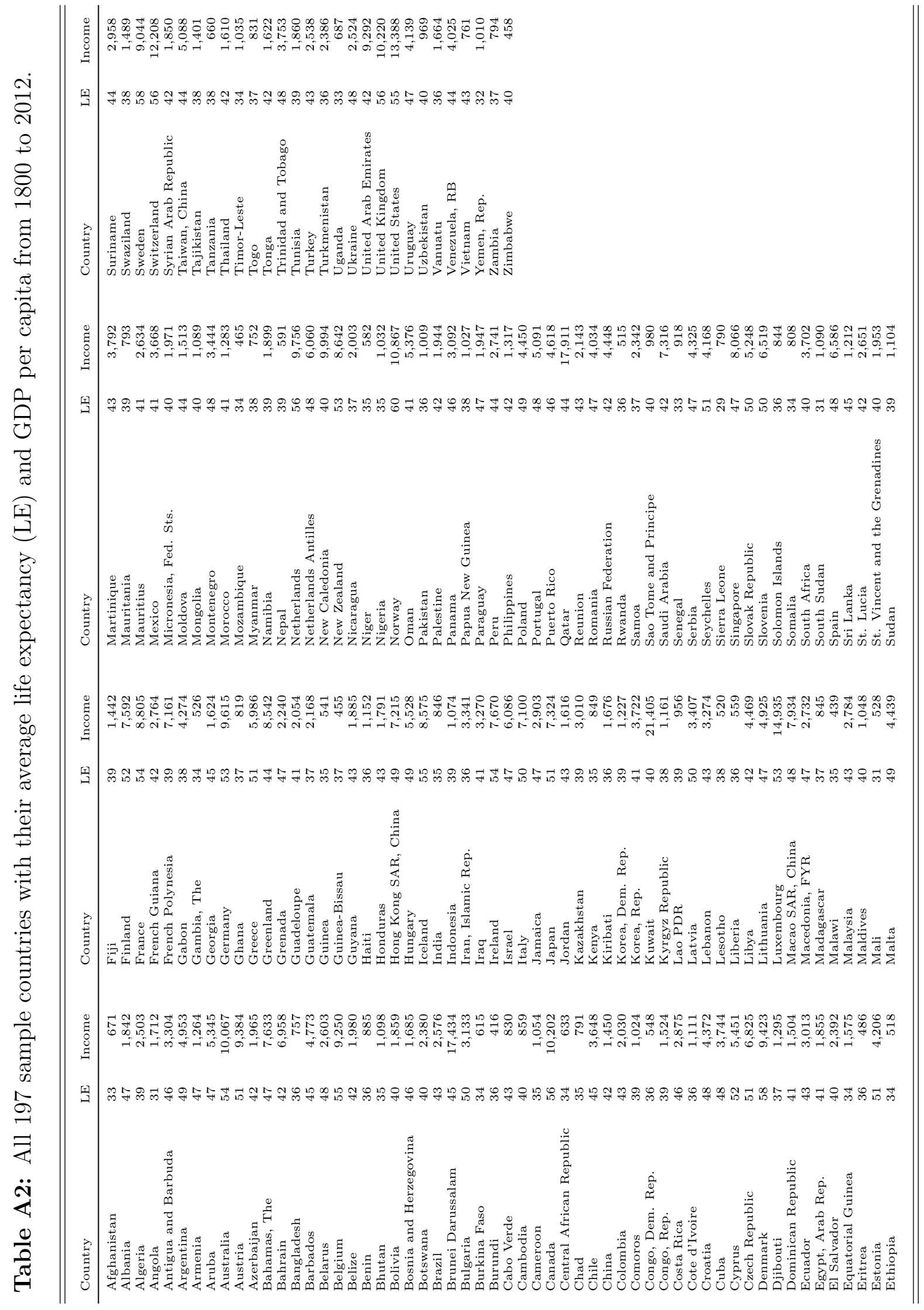


Table A3: Results from OLS regressions, estimating life expectancy in years (1800-2012) and averaging over five, ten and 20 years.

\begin{tabular}{|c|c|c|c|}
\hline & $\begin{array}{c}(1) \\
5 \text { year avg }\end{array}$ & $\begin{array}{c}(2) \\
10 \text { year avg }\end{array}$ & $\begin{array}{c}(3) \\
20 \text { year avg }\end{array}$ \\
\hline \multicolumn{4}{|c|}{ Dependent variable: Life expectancy in years } \\
\hline GDP/cap in US $\$ 10,000$ & $\begin{array}{c}4.489^{* * *} \\
(1.284)\end{array}$ & $\begin{array}{c}4.100^{* * *} \\
(1.442)\end{array}$ & $\begin{array}{c}8.000^{* * *} \\
(1.572)\end{array}$ \\
\hline$(\mathrm{GDP} / \mathrm{cap} \text { in } \mathrm{US} \$ 10,000)^{2}$ & $\begin{array}{c}-1.670^{* * *} \\
(0.498)\end{array}$ & $\begin{array}{c}-1.617^{* * *} \\
(0.545)\end{array}$ & $\begin{array}{c}-3.300^{* * *} \\
(0.677)\end{array}$ \\
\hline$(\mathrm{GDP} / \mathrm{cap} \text { in } \mathrm{US} \$ 10,000)^{3}$ & $\begin{array}{c}0.127^{* * *} \\
(0.041)\end{array}$ & $\begin{array}{c}0.126^{* * *} \\
(0.045)\end{array}$ & $\begin{array}{c}0.302^{* * *} \\
(0.069)\end{array}$ \\
\hline Population size & $\begin{array}{l}1.589^{* *} \\
(0.704)\end{array}$ & $\begin{array}{l}1.684^{* *} \\
(0.734)\end{array}$ & $\begin{array}{l}1.573^{* *} \\
(0.667)\end{array}$ \\
\hline Conflict incidence & $\begin{array}{l}-0.169^{*} \\
(0.099)\end{array}$ & $\begin{array}{l}-0.116 \\
(0.071)\end{array}$ & $\begin{array}{l}-0.024 \\
(0.053)\end{array}$ \\
\hline Country \& time fixed effects & yes & yes & yes \\
\hline Country-specific time trends & yes & yes & yes \\
\hline Threshold value GDP / $\operatorname{cap}^{a}$ & 16,573 & 15,478 & 15,360 \\
\hline \# of countries & 197 & 197 & 197 \\
\hline \# of decades & 21 & 21 & 21 \\
\hline $\begin{array}{l}N \\
R^{2}\end{array}$ & 8,428 & 4,312 & 2,160 \\
\hline$R^{2}$ & 0.947 & 0.953 & 0.959 \\
\hline
\end{tabular}

Notes: Standard errors clustered on the country level are displayed in parentheses. ${ }^{*} p<0.10,{ }^{* *} p<0.05,{ }^{* * *} p<0.01$. ${ }^{a} \mathrm{GDP} /$ cap value above which the income-life expectancy link flattens out. 